\title{
Use of Dictionaries and Online Tools for Reading by Thai EFL Learners in a Naturalistic Setting
}

\author{
Atipat Boonmoh, School of Liberal Arts, \\ King Mongkut's University of Technology Thonburi, \\ Bangmod, Thailand (atipat.boo@kmutt.ac.th)
}

\begin{abstract}
Dictionaries and online tools are regarded as important tools for finding out the meanings of unknown words or checking the usage of interesting words. This study investigated students' use of dictionaries and online tools in a natural setting by identifying the type of words they look up in their dictionaries and the types of dictionaries they use for the look-up. Fourteen learners from a Thai public university participated as the subjects by filling in a task record form which included the names of the dictionaries they were using, look-up words, meanings selected for the words, and their parts of speech. The look-up words were analyzed to find out the frequencies of words, parts of speech, and meanings by checking with an advanced learner dictionary. The findings show that the subjects mainly selected words that were nouns, verbs, and adjectives. They tended to choose "high frequency" for the lookups. For their convenience, subjects used either an online translation tool, 'Google Translate', or bilingual dictionaries through mobile devices. The results may help us understand EFL dictionary users' behaviors in using dictionaries and provide interesting implications for language teachers.
\end{abstract}

Keywords: DICTIONARY USE, DICTIONARY LOOKUPS, THAI EFL LEARNERS, GOOGLE TRANSLATE, DICTIONARY RECORD FORM, ONLINE DICTIONARIES

Opsomming: Thaise EVT-leerders se gebruik van woordeboeke en aanlyn hulpmiddels vir lees in 'n natuurlike omgewing. Woordeboeke en aanlyn hulpmiddels word as belangrike werktuie beskou om die betekenisse van onbekende woorde te bepaal of om die gebruik van interessante woorde na te gaan. In hierdie studie is studente se gebruik van woordeboeke en aanlyn hulpmiddels in 'n natuurlike omgewing bestudeer deur die tipe woorde wat deur hulle nageslaan word in hul woordeboeke asook die tipe woordeboeke wat hulle vir die naslaanproses gebruik, te identifiseer. Veertien leerders van 'n Thaise staatsuniversiteit het as proefpersone deelgeneem deur ' $n$ taakkontrolevorm te voltooi wat die name van die woordeboeke wat hulle gebruik het, die woorde wat nageslaan is, die betekenisse wat vir die woorde geselekteer is, en hul woordsoorte, ingesluit het. Die woorde wat nageslaan is, is geanaliseer om die frekwensies van woorde, hul woordsoorte, en betekenisse te bepaal deur 'n gevorderde aanleerderswoordeboek te raadpleeg. Die bevindings dui daarop dat die proefpersone hoofsaaklik substantiewe, werkwoorde en adjektiewe geselekteer het. Hulle was geneig om voorkeur aan "hoëfrekwensie" in 
die naslaanproses te verleen. Geriefshalwe het die proefpersone óf ' $n$ aanlyn vertalingshulpmiddel, 'Google Translate', óf tweetalige woordeboeke met behulp van mobiele toestelle gebruik. Die resultate mag ons dalk help om EVT-gebuikers se gedrag in die gebruik van woordeboeke te verstaan en lewer interessante implikasies vir taalonderwysers.

Sleutelwoorde: WOORDEBOEKGEBRUIK, WOORDEBOEKNASLAANPOGINGS, THAI EVT-LEERDERS, GOOGLE TRANSLATE, WOORDEBOEKKONTROLEVORM, AANLYN WOORDEBOEKE

\section{Introduction}

A dictionary is an essential tool when learning a foreign language. Learners consult their dictionaries for many purposes for different tasks. In a reading task, learners are likely to consult their dictionaries to find out the meaning of unknown or unfamiliar words. The main focus for dictionary use for reading as suggested by Schofield (1982) is to find out the specific meaning that is relevant to the context of the unfamiliar word or phrase, rather than to find out its spelling or grammatical characteristics. Learners can find the information about the meaning by using either a monolingual learner's dictionary or a bilingual (L2>L1) dictionary.

In recent years, it has been shown that new technology is being integrated into our lives at a great rate. The widespread use of mobile devices, especially computers and smartphones, significantly changes the ways of learning in many contexts, including language learning (Kukulska-Hulme 2009). This also changes the ways students consult their dictionaries, and internet or online dictionaries have gained popularity among EFL students (Dashtestani 2015). A number of studies (e.g., Fallianda 2020, Alhatmi 2019, Metruk 2017, Aslan 2016, Anongchanya and Boonmoh 2015, Ding 2015) have shown a growing number of online dictionary users in many countries around the world.

In Thailand, the number of smartphone users have increased rapidly. Studies into dictionary use (e.g. Boonmoh 2018, Chotkarnchanawat et al. 2017, Inpin 2016) show that students reported using dictionaries and online dictionaries both in classrooms and at home. Although online dictionaries are common in Thailand, they tend to be ignored by language teachers. Few studies that investigated dictionaries and online tools were conducted in classroom settings where their look up behavior may be different from natural settings.

Dictionary use is a private activity and the learners are often inclined to be secretive (Nesi and Boonmoh 2009), especially when they are of low L2 proficiency and when they feel that their teachers disapprove of the types of dictionaries they use. The choice of dictionary type also depends on individual learners. A number of previous studies (Liang and Xu 2018, Ding 2015, Dziemianko 2010) into dictionary use have been conducted in controlled experimental settings i.e., controlling the use of a specific type of dictionaries, the type of reading 
passages, the controlled setting of the experiment and the time spent. However, the findings may not be applicable to a real context where learners can choose which texts to read and to freely consult any dictionaries. This study, therefore, aims to find out which dictionaries students use and what type of words students look up in dictionaries when they are reading passages in their own free time.

\section{Literature Review: Uncovering dictionary use}

There are different methods to investigate dictionary use and dictionary lookup behavior. The following are a few but detailed reviews of previous studies with special reference to the methods used, which provide justification for the choice of this study's methodology.

One of the most common methods to research dictionary use is perhaps questionnaire research. Many studies in dictionary research (Fallianda 2020, Hojatpanah and Dashtestani 2020, Alhatmi 2019, Abbasi et al. 2019, Chotkarnchanawat et al. 2017, Aslan 2016, Boonmoh 2010) have employed this method. Although questionnaire survey research can be used as a way of obtaining results from a great number of respondents and has the potential for generating and testing a hypothesis because the large number of respondents can also mean better representation of the whole population, one basic problem associated with this type of survey as discussed by Nesi (2000) is the accuracy of responses. It is difficult for subjects to give correct information for questions which require them to recall their previous dictionary use behaviors. Some questions may require a capacity to recall, retrospect and comprehend beyond the abilities of the average dictionary user. Crystal (1986: 78) points out that retrospective questionnaire items place high demands on subjects' memories. He even challenges if anyone could "confidently write down when they last used a dictionary, why they used it, and how often they consult one". For this reason, it may not be a good idea to use questionnaires to investigate dictionary use behavior.

Interviews can be used to elicit opinions, and interactive settings are another step towards gathering more direct evidence of dictionary look-up behavior. Previous research which employs interviews together with other research instruments includes Hojatpanah and Dashtestani 2020, Baskin and Mumcu 2018, and Dashtestani 2013). The interview questions can be structured but can also be flexible in the sense that interviewers may ask further questions related to the interviewees' replies. It has been suggested, however, (e.g., Gorden 1980) that the more structured the interview, the more interviewees will feel like 'subjects' rather than 'informants'. Making the interviewees feel like 'subjects' might affect how they supply information as they might try to please researchers by providing information that they think we want to hear. Another basic problem when using an interview as a research instrument is similar to a problem using a questionnaire. The responses may not be accurate. Hatherall 
(1984: 184) questioned the success of questionnaire data as a means of recording subjects' behavioral acts: "Are subjects here saying what they do, or what they think they do, or what they think they ought to do, or indeed a mixture of all three?

Observation can be an effective way to describe dictionary use behavior as Hatherall (1984) recommends that watching dictionary users in action is "the only reliable method of collecting data on dictionary user behavior". It is, however, very difficult for teachers or researchers to see what is happening during a student's dictionary consultation as the dictionary consultation is a private activity. A less obstructive method to observe how dictionaries are used can be done by using 'log file' on computers. 'Log file' is a file that lists actions that have occurred (through keystroke logging). With log file analysis tools, it is possible to record all information about the use of a computer: what users key in, what they delete, what words in a dictionary they look up, etc. Studies that have employed log files include, for example, Koplenig et al. (2014), Chen (2011), Laufer and Levitzky-Aviad (2006), and Hulstijn and Trompetter (1998). Some limitations of using 'log file' as a research instrument listed by Lew (2015) are that "log files will rarely tell us what the context of dictionary use is: what activity the user is involved in, what particular problem they are trying to solve, and the level of success and satisfaction achieved in the consultation". Since this study aims at looking at dictionary use in a naturalistic setting, learners will not be restricted to using only dictionaries on computers but may also access dictionaries on their own devices and/or in printed forms.

Another method of investigating dictionary use involves lookup record forms. Some studies that have employed this method are Atkins and Varantola (1998), Diab and Hamdan (1999), Al-Ajmi (2002), and Frankenberg-Garcia (2005). These studies were conducted in a natural setting, reducing the likelihood of producing distorted data. Using dictionary record form, each subject could do the work at their own pace and they could use their dictionaries to solve their reading problems without being observed. However, asking students to record words they look up may not be appropriate for research into how dictionaries are really used. This is because the focus of the study (by using lookup record forms) would be on the final decision of the students rather than on the entire lookup process.

More studies using more naturalistic approach are needed to explore how learners use dictionaries in real situations, particularly in language learning contexts such as reading, writing and translation (Liang and $\mathrm{Xu}$ 2018), as dictionary consultation is a private matter and there is no way of discovering what people actually do when they use a dictionary without interfering with their natural behavior. Using a questionnaire would require too much memory recall from the students. Using a log file can help reveal this, but it is limited to observing dictionary use on mobile devices. When learners access their dictionaries or reference tools in printed format, log files cannot be used. Observation can look at how students use dictionaries in a natural setting but the fact that the students are being observed may affect their dictionary use behaviors. 
Asking the students to verbalize would inevitably disrupt the subjects' working processes. Using a dictionary record form can reveal only the final production of dictionary use i.e., what words they looked up for their reading. Taking all the type of research methods into consideration, the most appropriate research method for this study is, therefore, the use of a dictionary record form since the purpose of this study is purely to investigate the type of dictionaries and the type of words the students look up in dictionaries when they are reading passages at a time and place of their choice, and they can read and look up words at their own speed without any disruption.

\section{Purposes of the study}

The purposes of this study are to find out the following.

(a) What types of words were selected?

(b) From the selected words, what frequency level do they belong to?

(c) What types of dictionaries did students use?

\section{Methodology}

\section{Participants}

The participants of this study were 14 learners who enrolled in an English course entitled "Reading and Vocabulary Level 2" in the academic year 2020. These 14 learners were support staff members at a Thai public university in Bangkok, Thailand. Under the university Training Roadmap, six English courses were available for the staff: Reading and Vocabulary Level 1 and Level 2, Listening and Speaking Level 1 and Level 2, and Writing and Grammar Level 1 and Level 2. The 14 participants were from different departments/divisions of the university. Their ages ranged from 34 years old to 53 years old. Of these, 12 had at least a bachelor's degree and the remaining two participants had vocational diplomas. Their English language proficiency was considered low. These participants were chosen for two reasons. First, they enrolled in and attended the course voluntarily. Second, the content of the course was about strategies in learning vocabulary and strategies in reading. The course aimed to develop vocabulary knowledge through reading and also involved reading strategies, dealing with unknown words, and using dictionaries.

\section{Data collection}

\section{The reading text}

As a part of the course requirement, the students needed to complete a sum- 
mary task where they had to select a news article in English, read it thoroughly at their own pace and at a time and place of their choice, and write a summary in Thai. The news articles were chosen because they could lead students to many benefits such as increasing their awareness and motivation and encouraging them to bring a sense of reality and authenticity to the classroom (Rao 2019).

Ten news articles were taken and adapted from a BBC website and students were given choices to choose one of these ten articles which included a variety of news such as business, education, entertainment, environment, science and technology, and national and international issues:

- Air pollution: Thailand schools still closed due to 'unhealthy' smog levels (247 words)

- Could your firm move to a four-day week? (389 words)

- EU-Swiss share trading row: What does it mean? (325 words)

- Fukushima nuclear disaster: Abandoned town allows first residents home (215 words)

- Jack Ma defends the 'blessing' of a 12-hour working day (338 words)

- Salmon farming 'pays $£ 100 \mathrm{~m}$ in British taxes' (392 words)

- Starbucks to pay staff tuition fees (371 words)

- Tesla to raise prices and keep more stores open (394 words)

- TikTok app banned by US Army on work mobile phones (354 words)

- Where we are with Brexit - in 300 words (355 words)

\section{Dictionaries and online tools}

At the beginning of the course, the students were introduced to different types of dictionaries and online tools that are useful for reading. For the summary task, the students were instructed to use any dictionary of their choice i.e., bilingual or learner's dictionaries, online dictionaries from computers, or dictionaries or applications on mobile devices.

\section{Task record form}

After the students chose the news articles, they were given one week to complete the summary task. They were instructed to do this task at their own pace and at a time and place of their choice. The students had to submit two documents: the summary, and the task record form which included information about (1) their reason for choosing the news article, (2) looked-up words, their meanings, and word classes, and (3) the type and the specific name of the dictionary used. (See Appendix A for the task record form.) 


\section{Data analysis}

The researcher studied the elicited data and tabulated them accordingly i.e., looked-up words, their word classes, and their word frequency were put in a spreadsheet. All the looked-up words were analyzed to see whether the words fell in High, Mid, or Low-frequency words based on Longman Communication 9000 (LC9000) in Longman Dictionary of Contemporary English Online 6th edition (LDOCE), which is based on 390 million words in the Longman Corpus Network. This dictionary was chosen because of two reasons. First, it contains features typically found in major advanced learners' dictionaries. Second, this dictionary is well-known in Thailand.

LDOCE contains words appearing in the Academic Word List (AWL). These are important words to know when reading and writing academic assignments. It also provides the Longman 9000 keywords (LC9000) which are the most important 9,000 words to learn in English. The words can be classified into three levels: High frequency words, Mid frequency words, and Low frequency words. The three red dots indicate the top 3000 words, the two red dots indicate the next most important words, and the one red dot indicates the less frequent yet important next 3000 words.

However, in this dictionary there are some other words which do not belong to any of the 3 categories. These words occur less frequently than others, but they are still important and deserve an entry in the dictionary.

From the raw data, the reasons for choosing the news articles were noted, and the total number of looked-up words was counted and categorized into two themes: word classes and word frequency. The names of dictionaries were counted and classified. (See Appendix B for full details of all lookups.) The data from students' written summaries were not used in the analysis.

\section{Findings}

It can be seen from Table 1 that only four (out of ten) news articles were chosen by the students. P1 to P4 chose to read the article about air pollution in Thailand and P5 to P8 chose to read about a nuclear disaster in Fukushima. The next three students (P9 to P11) chose to read about an American multinational chain of coffeehouses called Starbucks and the remaining three students (P12 to P14) chose to read about a video-sharing social networking service called TikTok. When asked about the reasons, common themes emerging from this were having some background knowledge of the topic or having familiarity with the topic, having interest in the topic, and the short length of the news article. 
Table 1: News article read by students, their reasons for choosing it and number of dictionary lookups

\begin{tabular}{|c|c|c|c|}
\hline Students & News Article Read & Reasons & $\begin{array}{l}\text { Number of } \\
\text { Lookups }\end{array}$ \\
\hline P1 & \multirow{4}{*}{$\begin{array}{l}\text { Air pollution: Thailand } \\
\text { schools still closed due to } \\
\text { 'unhealthy' smog levels }\end{array}$} & $\begin{array}{c}\text { I think it will not be too } \\
\text { difficult. }\end{array}$ & 15 \\
\hline $\mathrm{P} 2$ & & It's about Thailand. & 11 \\
\hline P3 & & $\begin{array}{c}\text { I have some background } \\
\text { knowledge. }\end{array}$ & 8 \\
\hline $\mathrm{P} 4$ & & $\begin{array}{l}\text { Familiar content so it will be } \\
\text { easy to understand. }\end{array}$ & 13 \\
\hline P5 & \multirow{4}{*}{$\begin{array}{l}\text { Fukushima nuclear } \\
\text { disaster: Abandoned } \\
\text { town allows first } \\
\text { residents home }\end{array}$} & $\begin{array}{c}\text { I have some background } \\
\text { knowledge. }\end{array}$ & 15 \\
\hline P6 & & $\begin{array}{c}\text { It is the shortest. It seemed to } \\
\text { be the easiest. }\end{array}$ & 11 \\
\hline P7 & & It's short. & 9 \\
\hline P8 & & $\begin{array}{c}\text { I want to keep updated } \\
\text { about it. }\end{array}$ & 10 \\
\hline P9 & \multirow{3}{*}{$\begin{array}{l}\text { Starbucks to pay staff } \\
\text { tuition fees }\end{array}$} & I like Starbucks Coffee. & 10 \\
\hline P10 & & I know about Starbucks. & 11 \\
\hline P11 & & Interesting & 10 \\
\hline P12 & \multirow{3}{*}{$\begin{array}{c}\text { TikTok app banned by US } \\
\text { Army on work mobile } \\
\text { phones }\end{array}$} & $\begin{array}{c}\text { My daughter uses it and I } \\
\text { want to know why it is } \\
\text { banned. }\end{array}$ & 17 \\
\hline P13 & & $\begin{array}{l}\text { I heard about it and want to } \\
\text { know more. }\end{array}$ & 12 \\
\hline P14 & & My children use it. & 13 \\
\hline \multicolumn{3}{|c|}{$\begin{array}{c}\text { Total number of lookups } \\
95(\text { Noun })+44(\text { Verb })+22(\text { Adjective })+4(\text { Adverb }) \\
\end{array}$} & 165 \\
\hline
\end{tabular}

In terms of dictionary lookups, the total number of consultations completed by all the 14 subjects were 165 . The number of lookups completed by each subject ranged from 8 to 17 . The average lookups were 12. Of these 165, $95(57.6 \%)$ lookups were words classified by LDOCE as nouns, $44(26.7 \%)$ lookups were classified as verbs, and $22(13.3 \%)$ lookups were classified as adjectives. Adverbs were among the least common words that the subjects looked up in the dictionaries. These only accounted for $4(2.4 \%)$ lookups which were "currently, recently, increasingly", and "partially". It should be noted that the total number of lookups does not equate the total number of words. This is because some words were looked up by several students. For example, the word 'plant' was looked up by 4 students, the word 'Chernobyl' was looked up by 3 students, the word 'decontamination' was looked up by 2 students. There were altogether 9 lookups, but these lookups are counted as three words. (See Appendix B for full details of all lookups and words.) 
Since the subjects chose the article of their choice to read, there are certainly words that they did not know the meaning of or words that could help them with their comprehension. The words that they were likely to look up might be content words and specific words that they need to know about the topic being read. For example, "EU, Arizona, Brexit, Pret a Manger" were looked up by the subjects who read the article "Starbucks to pay staff tuition fees". It is obvious that most of the lookups were content words i.e., nouns, verbs, and adjectives, because these words carry meanings and must be included in a sentence for it to make sense, while the others were function words which only add proper grammatical structure and flow to the sentence. This might explain why the subjects looked up more content words and specific words than function words.

Table 2: Lookups classified by frequencies

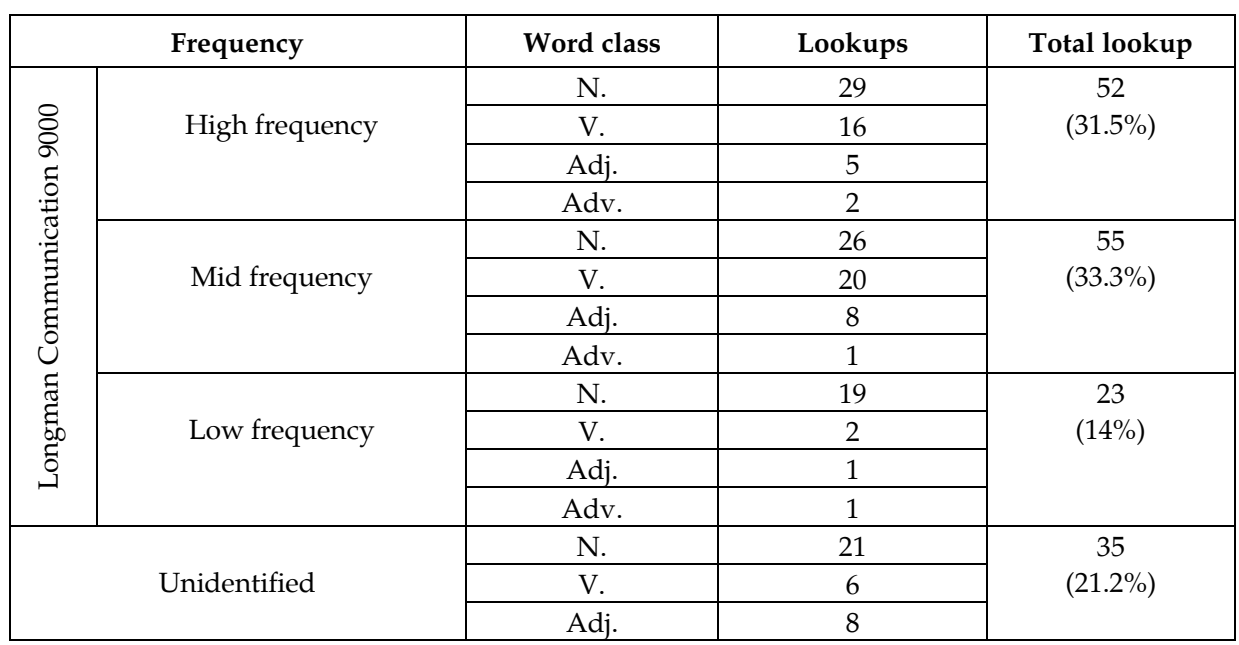

From Table 2, upon examining the subjects' frequency of lookup words, it can be seen almost $80 \%$ of all the lookups (130 lookups) were words that are listed in the LC9000. Of these, 52 lookups (31.5\%) belong to the High-frequency category, and 55 lookups (33.3\%) belong to the Mid-frequency category, and 23 lookups (14\%) belong to the Low-frequency category.

Only 35 lookups were classified as unidentified because the frequency marks are not shown in the Longman Dictionary of Contemporary English. These are, for example, "Chernobyl, Arkansas, Arizona, Brexit, EU, Pret A Manger, Newsroom, tsunami, haze, incense" for nouns, "Hosing, expediting, lip-synching" for verbs, and "grainier, toxic, quirky" for adjectives. 
Table 3: Examples of Lookups classified by Longman Communication 9000

\begin{tabular}{|c|c|c|c|c|}
\hline \multirow[t]{2}{*}{ Participants } & \multirow{2}{*}{$\begin{array}{l}\text { Titles of news } \\
\text { articles }\end{array}$} & \multirow{2}{*}{$\begin{array}{l}\text { Lookups listed in } \\
\text { LC9000 }\end{array}$} & \multicolumn{2}{|c|}{ Unidentified } \\
\hline & & & & Proper noun \\
\hline $\begin{array}{l}\text { P1 } \\
\text { P2 } \\
\text { P3 } \\
\text { P4 }\end{array}$ & $\begin{array}{c}\text { Air pollution: } \\
\text { Thailand schools } \\
\text { still closed due to } \\
\text { 'unhealthy' smog } \\
\text { levels }\end{array}$ & $\begin{array}{l}\text { effect, cases, lung, } \\
\text { smog, exhaust, blame, } \\
\text { reduce, tackle, tiny, } \\
\text { unhealthy, harmful }\end{array}$ & $\begin{array}{l}\text { Haze, incense, } \\
\text { hosing, } \\
\text { grainier, toxic }\end{array}$ & - \\
\hline $\begin{array}{l}\text { P5 } \\
\text { P6 } \\
\text { P7 } \\
\text { P8 }\end{array}$ & $\begin{array}{c}\text { Fukushima } \\
\text { nuclear disaster: } \\
\text { Abandoned town } \\
\text { allows first resi- } \\
\text { dents home }\end{array}$ & $\begin{array}{c}\text { plant, inhabitants, } \\
\text { recovery, radiation, } \\
\text { infrastructure, accuse, } \\
\text { flee, vast }\end{array}$ & $\begin{array}{l}\text { tsunami, } \\
\text { expediting }\end{array}$ & Chernobyl \\
\hline $\begin{array}{l}\text { P9 } \\
\text { P10 } \\
\text { P11 }\end{array}$ & $\begin{array}{l}\text { Starbucks to pay } \\
\text { staff tuition fees }\end{array}$ & $\begin{array}{l}\text { employee, tuition, } \\
\text { incentive, under- } \\
\text { graduate, enroll, offer, } \\
\text { obtain, financial, } \\
\text { available } \\
\end{array}$ & - & $\begin{array}{l}\text { Brexit, EU, } \\
\text { Pret A } \\
\text { Manger, } \\
\text { Arizona }\end{array}$ \\
\hline $\begin{array}{l}\text { P12 } \\
\text { P13 } \\
\text { P14 }\end{array}$ & $\begin{array}{l}\text { TikTok app } \\
\text { banned by US } \\
\text { Army on work } \\
\text { mobile phones }\end{array}$ & $\begin{array}{c}\text { cyber threat, policies, } \\
\text { privacy, authorities, } \\
\text { scrutiny, hire, restrict, } \\
\text { issue, wary } \\
\end{array}$ & $\begin{array}{c}\text { lip-synching, } \\
\text { quirky }\end{array}$ & Arkansas \\
\hline
\end{tabular}

Table 3 shows some words that were searched by the students in order to complete the summary task. It is clear most searched words are content words and are listed in the LC9000 (Also see Appendix B). These searched words are important for the students as they help the students to comprehend the news articles effectively.

For example, Participant 10 looked up these 11 words: "incentive, initial, expand, obtain, Brexit, Pret A Manger, firm, offer, undergraduate, financial, reduce". These are key words that help Participant 10 understand the main idea of the news article 'Starbucks Coffee offers an incentive to its staff in UK who want to obtain an undergraduate degree by giving financial support to them'.

Taking the titles of articles into consideration, it is obvious that many of the lookups that are classified as unidentified are proper nouns or words that are specially related to the specific topics the participants chose to read. For example, the words "haze, incense, hosing, and toxic" were searched by students as these words are related to the 'toxic haze that can be reduced by hosing down the streets and not burning incense'. The proper nouns "EU, Arizona, Brexit, Pret a Manger" were looked up as it specifically discussed about 'recruitment problems Pret a Manger may encounter after Brexit from the EU'

Although this study did not take the success of dictionary consultation and the correctness and overall quality of the written summaries into account, it should be noted that some subjects misunderstood the news articles. Part of 
this misunderstanding was due to their dictionary lookups. For example, Participant 6 looked up the word 'plant' from Google Translate and wrote the meaning "ปลูก" / to plant/ in the dictionary record sheet. His written summary talks about planting trees nearby Fukushima power plant.

Table 4: Dictionaries and online tools consulted by students

\begin{tabular}{|c|c|c|c|c|c|c|c|c|c|c|c|c|c|c|c|}
\hline \multirow{2}{*}{ Dictionaries and Online Tools } & \multicolumn{14}{|c|}{ Participants who used this type } & \multirow{2}{*}{ Total } \\
\hline & 1 & 2 & 3 & 4 & 5 & 6 & 7 & 8 & 9 & & 11 & & 13 & $\overline{14}$ & \\
\hline Google Translate & / & l & / & I & I & / & l & / & / & I & / & l & / & / & 14 \\
\hline www.google.com & & & & & & & & & & / & l & l & & & 3 \\
\hline Longdo Dict & & & & & & l & & & & & & & & & 1 \\
\hline Sanook Dict & & & & & & & & & l & & & & & & 1 \\
\hline Line Dict & & & & & & & I & & & & & & & & 1 \\
\hline LDOCE & & & & & l & & & & & & & & & & 1 \\
\hline Se-Ed's Modern English-Thai dictionary & I & & I & & & & & & & & & & & & 2 \\
\hline Total & 2 & 1 & 2 & 1 & 2 & 1 & 2 & 1 & 2 & 2 & 2 & 2 & 1 & 1 & 23 \\
\hline
\end{tabular}

Table 4 shows the proportion of dictionaries and online tools that the 14 students consulted while reading the news articles. Google Translate is by far the most popular online translation tool that they used for the summary task. All 14 students used Google Translate from their mobile devices. It can be seen that not everyone uses only one dictionary. All 14 students used Google Translate as a base dictionary and some students used other dictionaries.

Three students used websites such as www.google.com to search for unknown words. For example, in the task record form, Participant 10 wrote that he looked up the word "Pret A Manger" from Google Translate, but the translation was "แกล้งทำเป็นรางหญ้า" / pretend to be a manger/. He then looked up "Pret A Manger" from www.google.com. and later understood that it is a name of a well-known sandwich company. Interestingly, Participant 12 reported in the task record form about searching for the words "military, army, navy, Arkansas" from Google Images.

Three students used online English-Thai dictionaries from their mobile devices. Online English-English dictionaries were the least popular as can be seen that only one participant reported using Longman Dictionary of Contemporary English Online. This may be because LDOCE was used as an example of a learner's dictionary introduced to the students at the beginning of the course. It is also interesting to note that taking the mode of dictionaries into consideration, online-based dictionaries outnumber paper-based dictionaries by 18 to 2 . Only two students used an English-Thai dictionary in book format for this summary task. 


\section{Discussion and Conclusion}

This study reveals insights into how the students selected a news article of their own choice to read at their own time, the type of words they looked up from their dictionaries and online tools as well as their choice of those tools used to complete the summary task in a naturalistic setting.

The findings of this study showed that when choice and adequate time were given, students chose to read the news articles based on their familiarity or the background knowledge they had on the topic, their interests, and the perceived difficulty of the text. This finding is obvious, but it can provide some implications for research design of receptive use of dictionary use research. In order to better understand students' dictionary use behavior, it is important that they can choose reading texts according to their own interests or they can have some degree of freedom to choose reading texts. They would be more motivated to engage with the text (Butcher and Kintsch 2003), and the more background knowledge they have on the text, the more likely they will be able to make sense of what is being read (Pardo 2004).

In the analysis of word types and their frequency, it is found that the students looked up content words (noun, verb, adjective: 97.6\%) much more than function words (adverbs: $2.4 \%$ ). This finding is not surprising because in any given text it is typical that the number of content words is higher than function words. The fact that the subjects looked up fewer adverbs might be because there were fewer of these than other kinds of content word in the text. On the other hand, content words are words that are related to both meaning and comprehension, and acquisition of content words is essential for successful second language use. Content words are usually polysemous (Crossley et al. 2010), they carry multiple meanings which can cause problems for students in meaning comprehension. This may explain why content words were looked up much more than function words. This finding is consistent with that of Liang and $\mathrm{Xu}$ (2018) who reported Chinese learners indicated their tendency to look up content words more than function words.

The study also showed that the students consulted high-frequency words most often as can be seen that $80 \%$ (130 out of 165) of all lookups are listed in the LC9000. This finding corresponds to that of Liang and Xu (2018) and Koplenig et al. (2014). The high proportion of high-frequency words that were looked up may reflect the fact that students' vocabulary was limited and they relied heavily on dictionaries and online tools to comprehend their meaning.

In terms of the students' choice of dictionaries and online tools, analysis of the data indicated that the students used bilingual dictionaries more frequently than monolingual ones as well as used online dictionaries more than paper-based dictionaries. This accords with a survey finding conducted by Fallianda (2020) that pre-intermediate and intermediate students use bilingual dictionaries more often than monolingual dictionaries. The finding of this study is also consistent with those in Tong (2019), Małgorzata (2016), and Dashtestani (2013) in 
that bilingual and online dictionaries were the most popular among the students.

This study found that an overwhelming number of students reported that they used Google Translate to do the summary task. This finding is similar to Małgorzata's investigation (2016) that the students highlighted their preference for online dictionaries and online resources rather than traditional paper dictionaries. However, it is interesting to note that 'Google Translate' is not a dictionary. It is an online translating tool, but it has gained much popularity from many users from which can be inferred that the students found it convenient to find the meaning of words. Even though teachers encourage students to use learner's dictionaries (Boonmoh 2010), the students seemed to prefer to use other online dictionaries and tools when they have access to their own mobile devices.

Interestingly, the finding of the current study is contrary to that of Ding (2015) and Diab and Hamdam (1990) who found that monolingual dictionaries were preferred by their students. This may be explained by the fact that the students of these two studies were English major students who presumably were advanced learners of English, and they used dictionaries in their translation classes. Another explanation is related purpose of dictionary use. Using a dictionary for translation task and using a dictionary for a summary may affect the choice of dictionary use. Since the students in the current study were lower intermediate learners of English and they preferred bilingual dictionaries, this may suggest that they are not confident enough about their English and they might feel more comfortable using bilingual dictionaries than English-English dictionaries as they could understand the meanings of the target words right away. This can be further supported by Corrius and Pujol (2010) in that bilingual dictionaries generate confidence among users.

\section{Conclusion}

This study investigated the use of dictionaries and online tools by students in a naturalistic setting by identifying students' justification when selecting a news article to read in their own time and exploring the frequency and type of words looked up in dictionaries and online tools by the students. It also identified dictionaries and online tools used by the students.

Based on the findings, it can be proposed that when teaching students in a reading class, teachers should select reading passages that are authentic and relevant to students' background knowledge. Students should be allowed an opportunity to choose to read a text of their interest and at their own time. As acquisition of content words is essential for successful second language use, teachers may consider providing explicit training in dictionary use. Teacher may introduce the students to different learners' dictionaries and provide information on the criteria according to which dictionaries determine the priority in vocabulary and word frequency (Metruk 2017). For example, the 
LC9000 features in LDOCE can help students be well-informed in vocabulary learning and use. This will also help students know which words are assigned priority. Since words in high- and mid-frequency categories were looked up the most, this may suggest students' limited vocabulary knowledge. Therefore, teachers should not ignore vocabulary teaching and reading strategies so that the students can increase their reading proficiency.

One last important result emerging from this study is the frequent use of 'Google Translate'. Since this study was conducted in a natural setting and no particular dictionaries or online tools were imposed on the students, it is clear that the use of 'Google Translate' will become a fact of life for EFL learners in Thailand and other countries. This increase in "Google Translate' use will eventually affect classroom environments. The presence of "Google Translate" will continue, as Stirling (2005: 64) suggested "they seem to be here to stay, just as calculators, once welcomed by students and rejected by teachers, have stayed."

The decision whether to ignore "Google Translate" use in classroom or to help students make full use of "Google Translate" will depend on the teachers. Language teachers should explore this thoroughly in terms of advantages and disadvantages so that they can be in a position to train students to use "Google Translate" or to integrate Google Translate along with other online dictionaries effectively. For example, when using "Google Translate" to find the meaning of the words, the teachers should make the students beware that when using a dictionary or online tool to find the meaning of the words, they need to select the appropriate entries for the context so that they can better understand the text. Teacher may suggest alternative ways to look for meanings of the unknown words such as using Google Images.

This study provides insight into dictionaries and online tools use in natural setting. However, it has some limitations. The number of students in the study is not high. The meanings that the students supplied in the task record form after look-up were not taken into account although the finding is based on the task record form. Although the students were allowed to choose one of the ten news articles, the students were not entirely free to choose what they wanted to read. This might have provided a better picture of how the students use dictionaries and online tools to meet their reading needs. To improve these, future studies with a larger population, with free choice of text read and with mixed research methods should be conducted. Studies into success in dictionary consultation taking into account task record form should be conducted.

\section{References}

Abbasi, W.T., M.M. Ahmad, and F.A.E. Mohammed. 2019. Learners' Perceptions of Monolingual Dictionaries in Learning English as a Foreign Language. International Journal of Education $\mathcal{E}$ Literacy Studies 7(3): 10-18.

Al-Ajmi, H. 2002. Which Microstructural Features of Bilingual Dictionaries Affect Users' Look-up Performance? International Journal of Lexicography 15(2): 119-131. 
Alhatmi, S. 2019. A Survey Study of the Dictionary Use Sub-strategies of English Majors in Saudi Arabia: Dictionary Related Aspects. English Language Teaching 12(3): 139-160.

Anongchanya, E. and A. Boonmoh. 2015. The Effectiveness of the Use of Dictionary Applications in Smartphones in Reading an English-language Passage and Writing a Summary in Thai. Proceedings from ICLLCS 2015, 2nd International Conference on Language, Literature, and Cultural Studies, 20-21 August 2015, Chonburi, Thailand: 47-58. Saen Suk, Thailand: Department of Western Languages, Faculty of Humanities and Social Sciences, Burapha University.

Aslan, E. 2016. A Study on the Use of Mobile Dictionaries in Vocabulary Teaching. Journal of Language and Linguistic Studies 12(1): 1-8.

Atkins, B.T.S. and K. Varantola. 1998. Monitoring Dictionary Use. Atkins, B.T.S. (Ed.). 1998. Using Dictionaries: Studies of Dictionary Use by Language Learners and Translators: 83-122. Lexicographica. Series Maior 88. Tübingen: Max Niemeyer.

Baskin, S. and M. Mumcu. 2018. Dictionary Culture of University Students Learning English as a Foreign Language in Turkey. International Education Studies 11(3): 101-114. Doi: 10.5539/ies. v11n3p101.

Boonmoh, A. 2010. Teachers' Use and Knowledge of Electronic Dictionaries. ABAC Journal 30(3): 56-74.

Boonmoh, A. 2018. The Use of Online Dictionaries for Writing by Thai University Students. Proceedings from ICES 2018, the 1st International Conference on English Studies: "Innovation in English Language Teaching and Learning", Krabi, Thailand, 28-29 June 2018: 333-340. Muang, Songkhla: Department of Western Languages, Faculty of Humanities and Social Sciences, Thaksin University.

Butcher, K.R. and W. Kintsch. 2003. Text Comprehension and Discourse Processing. Healy, A.F. and R.W. Proctor. 2003. Handbook of Psychology: Experimental Psychology. Volume 4: 575-595. New York: John Wiley.

Chen, Y.Z. 2011. The Use of Bilingualized English-Chinese Learner's Dictionaries: A Survey and An Experiment. Lexicographical Studies 2: 141-158.

Chotkarnchanawat, R., C. Liangpanit and S. Wasuntarasophit. 2017. Graduate Students' Reflections on the Use of Online Dictionaries for Writing a Thesis. Journal of Humanities and Social Sciences 13(2): 223-246.

Corrius, M. and D. Pujol. 2010. A Bilingualised English Dictionary for Catalan Speakers. Lexikos 20: 109-122.

Crossley, S., T. Salsbury and D. McNamara. 2010. The Development of Polysemy and Frequency Use in English Second Language Speakers. Language Learning 60(3): 573-605.

Crystal, D. 1986. The Ideal Dictionary, Lexicographer and User. Ilson, R. (Ed.). 1986. Lexicography: An Emerging International Profession: 72-81. Manchester: University Press.

Dashtestani, R. 2013. EFL Teachers' and Students' Perspectives on the Use of Electronic Dictionaries for Learning English. CALL-EJ 14(2): 51-65.

Dashtestani, R. 2015. Moving Bravely Towards Mobile Learning: Iranian Students' Use of Mobile Devices for Learning English as a Foreign Language. Computer Assisted Language Learning 29(4): 815-832.

Diab, T.A. and J.M. Hamdan. 1999. Interacting with Words and Dictionaries: The Case of Jordan EFL Learners. International Journal of Lexicography 12(4): 281-305. 
Ding, J. 2015. A Study of English Majors in a Chinese University as Dictionary Users. Lexicography: Journal of Asialex 2(1): 5-34.

Dziemianko, A. 2010. Paper or Electronic? The Role of Dictionary Form in Language Reception, Production and the Retention of Meaning and Collocations. International Journal of Lexicography 23(3): 257-273.

Fallianda. 2020. A Survey of Indonesian Students' Use of Dictionaries. Lexikos 30: 609-628.

Frankenberg-Garcia, A. 2005. A Peek into What Today's Language Learners as Researchers Actually Do. International Journal of Lexicography 18(3): 335-355.

Gorden, R.L. 1980. Interviewing: Strategy, Techniques, and Tactics. Third edition. Homewood: IrwinDorsey.

Hatherall, G. 1984. Studying Dictionary Use: Some Findings and Proposals. Hartmann, R.R.K. (Ed.). 1984. LEXeter '83 Proceedings: Papers from the International Conference on Lexicography at Exeter, 9-12 September 1983: 183-189. Tübingen: Max Niemeyer.

Inpin, B. 2016. Smartphones: Noteworthy Tools for Enhancing EFL Students' English Language Learning. Academic Journal: Uttaradit Rajabhat University 11(1): 167-180.

Hojatpanah, S. and R. Dashtestani. 2020. Electronic Dictionaries as Language Learning Tools for Iranian Junior High School Students. CALL-EJ Online 21(1): 79-96.

Hulstijn, J.H. and P. Trompetter. 1998. Incidental Learning of Second Language Vocabulary in Computer-assisted Reading and Writing Tasks. Albrechtsen, D., B. Henriksen, I.M. Mees and E. Poulsen (Eds.). 1998. Perspectives on Foreign and Second Language Pedagogy: 191-200. Odense, Denmark: Odense University Press.

Koplenig A., P. Meyer and C. Müller-Spitzer. 2014. Dictionary Users Do Look Up Frequent Words. A Log File Analysis. Müller-Spitzer, C. (Ed.). 2014. Using Online Dictionaries: 229-250. Lexicographica Series Maior 145. Berlin/Boston: De Gruyter.

Kukulska-Hulme, A. 2009. Will Mobile Learning Change Language Learning. ReCALL 21(2): 157165.

Laufer, B. and T. Levitzky-Aviad. 2006. Examining the Effectiveness of 'Bilingual Dictionary Plus' A Dictionary for Production in a Foreign Language. International Journal of Lexicography 19(2): 135155.

Lew, R. 2015. Opportunities and Limitations of User Studies. OPAL - Online publizierte Arbeiten zur Linguistik 2015(2): 6-16.

Liang, P. and D. Xu. 2018. An Empirical Study of EFL Learners' Dictionary Use in Chinese-English Translation. Lexikos 28: 221-244.

Małgorzata, K. 2016. Dictionary-using Skills of Translation Students. The Central European Journal of Social Sciences and Humanities 4: 235-242.

Metruk, R. 2017. The Use of Electronic Dictionaries for Pronunciation Practice by University EFL Students. The Journal of Teaching English with Technology 17(4): 38-51.

Nesi, H. 2000. The Use and Abuse of EFL Dictionaries: How Learners of English as a Foreign Language Read and Interpret Dictionary Entries. Lexicographica Series Maior 98. Tübingen: Max Niemeyer.

Nesi, H. and A. Boonmoh. 2009. A Close Look at the Use of Pocket Electronic Dictionaries for Receptive and Productive Purposes. Fitzpatrick, Tess and Andy Barfield (Eds.). 2009. Lexical Processing in Second Language Learners: 67-81. Clevedon, UK: Multilingual Matters.

Pardo, L.S. 2004. What Every Teacher Needs to Know about Comprehension. The Reading Teacher 58(3): $272-280$ 
http://lexikos.journals.ac.za; https://doi.org/10.5788/31-1-1645 (Article)

Use of Dictionaries and Online Tools for Reading by Thai EFL Learners

Rao, P.S. 2019. The Impact of Using Newspapers on Teaching Language Skills to the Second Language Learners of English. ELT Vibes: International E-Journal For Research in ELT 5(2): 154-170.

Schofield, P. 1982. The Role of Bilingual Dictionaries in ESL/EFL: A Positive View. Guidelines 4(1): 84-98.

Stirling, J. 2005. The Portable Electronic Dictionary - Faithful Friend or Faceless Foe? Modern English Teacher 14(3): 64-72.

Tong, L.T.M. 2019. Vietnamese EFL Students' Habits of Using Dictionaries in Translation Practice in ESP Courses. Journal of English Language Teaching and Linguistics 4(3): 305-318. 
Appendix A: Dictionary Record form

1. Which news article did you choose to read?

2. Why did you choose this article?

3. What are the most interesting words that you learned? What words did you look up?

\begin{tabular}{|l|l|l|}
\hline Words & $\begin{array}{l}\text { Part of } \\
\text { speech }\end{array}$ & \\
\hline & & \\
\hline & & \\
\hline & & \\
\hline & & \\
\hline & & \\
\hline & & \\
\hline & & \\
\hline & & \\
\hline & & \\
\hline & & \\
\hline
\end{tabular}

4. Please write down the names of dictionaries and online tools that you used in this task.

(1)

(2)

(3) 
http://lexikos.journals.ac.za; https://doi.org/10.5788/31-1-1645 (Article)

Use of Dictionaries and Online Tools for Reading by Thai EFL Learners

Appendix B: Details of Lookups and words

\begin{tabular}{|c|c|c|c|c|c|c|c|c|c|}
\hline \multicolumn{10}{|c|}{ NOUN } \\
\hline No. & Words & $\begin{array}{l}\text { Classified } \\
\text { by LC9000 }\end{array}$ & Searched by & Frequency & No. & Words & $\begin{array}{c}\text { Classified } \\
\text { by LC9000 }\end{array}$ & Searched by & Frequency \\
\hline 1 & plant & High & P5 P6 P7 P8 & 4 & 31 & lungs & Medium & $\mathrm{P} 1$ & 1 \\
\hline 2 & army & High & P12 P14 & 2 & 32 & navy & Medium & P12 & 1 \\
\hline 3 & authorities & High & P5 P7 & 2 & 33 & personnel & Medium & P14 & 1 \\
\hline 4 & concern & High & P7 P13 & 2 & 34 & privacy & Medium & P14 & 1 \\
\hline 5 & military & High & P12 P13 & 2 & 35 & residents & Medium & P6 & 1 \\
\hline 6 & policies & High & P12 P13 & 2 & 36 & Spokeswoman & Medium & P11 & 1 \\
\hline 7 & quality & High & P2 P4 & 2 & 37 & strain & Medium & P11 & 1 \\
\hline 8 & threat & High & P12 P13 & 2 & 38 & \begin{tabular}{|c|} 
tuition \\
\end{tabular} & Medium & $\mathrm{P} 9$ & 1 \\
\hline 9 & attempt & High & P8 & 1 & 39 & undergraduate & Medium & P10 & 1 \\
\hline 10 & billion & High & P14 & 1 & 40 & infrastructure & Low & P5 P6 P7 P8 & 4 \\
\hline 11 & cases & High & $\mathrm{P} 4$ & 1 & 41 & autonomy & Low & P12 P13 P14 & 3 \\
\hline 12 & disaster & High & P8 & 1 & 42 & exhaust & Low & P1 P2 P4 & 3 \\
\hline 13 & effect & High & $\mathrm{P} 4$ & 1 & 43 & scrutiny & Low & P12 P13 P14 & 3 \\
\hline 14 & election & High & P14 & 1 & 44 & smog & Low & P1 P3 P4 & 3 \\
\hline 15 & fees & High & $\mathrm{P} 9$ & 1 & 45 & default & Low & P12 & 1 \\
\hline 16 & firm & High & P10 & 1 & 46 & particles & Low & $\mathrm{P} 1$ & 1 \\
\hline 17 & progress & High & P5 & 1 & 47 & radiation & Low & P7 & 1 \\
\hline 18 & scheme & High & P9 & 1 & 48 & Brexit & unidentified & P9 P10 P11 & 3 \\
\hline 19 & $\operatorname{tax}$ & High & P11 & 1 & 49 & Chernobyl & unidentified & P5 P6 P8 & 3 \\
\hline 20 & capabilities & Medium & P12 P14 & 2 & 50 & haze & unidentified & P1 P2 P3 & 3 \\
\hline 21 & incentive & Medium & P9 P10 & 2 & 51 & lecontamination & unidentified & P5 P8 & 2 \\
\hline 22 & inhabitants & Medium & P5 P6 & 2 & 52 & incense & unidentified & $\mathrm{P} 1 \mathrm{P} 4$ & 2 \\
\hline 23 & recovery & Medium & P5 P6 & 2 & 53 & Arizona & unidentified & $\mathrm{P} 11$ & 1 \\
\hline 24 & senators & Medium & P12 P13 & 2 & 54 & Arkansas & unidentified & P12 & 1 \\
\hline 25 & width & Medium & P2 P3 & 2 & 55 & bloodstream & unidentified & $\mathrm{P} 2$ & 1 \\
\hline 26 & critics & Medium & P5 & 1 & 56 & EU & unidentified & P9 & 1 \\
\hline 27 & diameter & Medium & $\mathrm{P} 4$ & 1 & 57 & Newsroom & unidentified & P1 & 1 \\
\hline 28 & employee & Medium & P11 & 1 & 58 & Pret a Manger & unidentified & $\mathrm{P} 10$ & 1 \\
\hline 29 & fragments & Medium & P1 & 1 & 59 & subscriber & unidentified & P14 & 1 \\
\hline 30 & Index & Medium & $\mathrm{P} 2$ & 1 & 60 & tsunami & unidentified & P8 & 1 \\
\hline \multicolumn{4}{|c|}{ Number of lookups } & 46 & \multicolumn{4}{|c|}{ Number of lookups } & 49 \\
\hline \multicolumn{10}{|c|}{ Total number of lookups $46+49=95$} \\
\hline
\end{tabular}




\begin{tabular}{|c|c|c|c|c|c|c|c|c|c|}
\hline \multicolumn{5}{|c|}{ VERB } & \multicolumn{5}{|c|}{ ADJECTIVE } \\
\hline No. & Words & $\begin{array}{c}\text { Classified } \\
\text { by LC9000 }\end{array}$ & $\begin{array}{c}\text { Searched } \\
\text { by }\end{array}$ & Frequency & No. & Words & $\begin{array}{l}\text { Classified } \\
\text { by LC9000 }\end{array}$ & Searched by & Frequency \\
\hline 1 & blamed & High & S1 S4 & 2 & 1 & tiny & High & S3 S4 & 2 \\
\hline 2 & failed & High & S1 S2 & 2 & 2 & available & High & S9 & 1 \\
\hline 3 & hired & High & S12 S13 & 2 & 3 & effective & High & S11 & 1 \\
\hline 4 & reducing & High & S4 S10 & 2 & 4 & financial & High & $\mathrm{S} 10$ & 1 \\
\hline 5 & celebrate & High & S4 & 1 & 5 & harmful & Medium & S1 S2 S3 & 3 \\
\hline 6 & cost & High & S11 & 1 & 6 & initial & Medium & S10 S11 & 2 \\
\hline 7 & forced & High & S2 & 1 & 7 & vast & Medium & S5 S6 & 2 \\
\hline 8 & include & High & S9 & 1 & 8 & unhealthy & Medium & S3 & 1 \\
\hline 9 & obtain & High & S10 & 1 & 9 & wary & Low & S12 & 1 \\
\hline 10 & offer & High & S10 & 1 & 10 & grainier & unidentified & S1 S2 S4 & 3 \\
\hline 11 & provide & High & S11 & 1 & 11 & abandoned & unidentified & S5 S6 & 2 \\
\hline 12 & remains & High & S8 & 1 & 12 & lunar & unidentified & S1 & 1 \\
\hline 13 & accused & Medium & S5 S6 S7 S8 & 4 & 13 & toxic & unidentified & S3 & 1 \\
\hline 14 & fled & Medium & S6 S7 S8 & 3 & 14 & quirky & unidentified & S12 & 1 \\
\hline 15 & issue & Medium & S12 S13 S14 & 3 & \multicolumn{4}{|c|}{ Total number of lookup } & 22 \\
\hline 16 & flee & Medium & S5 S7 & 2 & & & & & \\
\hline 17 & posed & Medium & S13 S14 & 2 & & & & & \\
\hline 18 & restrict & Medium & S13 S14 & 2 & \multicolumn{5}{|c|}{ ADVERB } \\
\hline 19 & expand & Medium & $\mathrm{S} 10$ & 1 & 1 & currently & High & S4 & 1 \\
\hline 20 & launch & Medium & S9 & 1 & 2 & recently & High & S14 & 1 \\
\hline 21 & strengthening & Medium & S12 & 1 & 3 & increasingly & Medium & S13 & 1 \\
\hline 22 & tackling & Medium & S1 & 1 & 4 & partially & Low & S6 & 1 \\
\hline 23 & deemed & Low & S5 & 1 & \multicolumn{4}{|c|}{ Total number of lookup } & 4 \\
\hline 24 & enroll & Low & S9 & 1 & & & & & \\
\hline 25 & hosing & unidentified & S1 S2 S3 & 3 & & & & & \\
\hline 26 & expediting & unidentified & S5 S7 & 2 & & & & & \\
\hline 27 & lip-synching & unidentified & $\mathrm{S} 12$ & 1 & & & & & \\
\hline \multicolumn{4}{|c|}{ Total number of lookup } & 44 & & & & & \\
\hline
\end{tabular}

